\title{
Tracing Mercado's Anthropological Perspective (Second of Two Parts)
}

\section{Emmanuel D. Batoon}

\begin{abstract}
The paper traces the significance of Leonardo N. Mercado's anthropological perspective on the study of Filipino philosophy and argues that the significance of his perspective lies in its bringing to light the Filipino people as a group of philosophers in their own right who constructed a worldview of their own and embodied it in their languages, behavior, and mythology that provides them with a mission and vision as a nation. To justify the argument, a content analysis of the book Elements of Filipino Philosophy was done in terms of Mercado's cultural philosophical theoretical framework, where philosophy is constructed by a group of ordinary people like Filipinos and the result is an empirical and observably unique but not idiosyncratic worldview like the Filipino worldview, ethnographic method that involves an ethno-linguistic analysis of the major Philippine languages, phenomenological observation of Filipino behavior, secondary data analysis of social scientist's analysis of Philippine mythologies, and findings on the conceptual elements of the Filipino worldview composed of a logos that describes the mode through which Filipinos construct their world, ontos that describes Filipinos' constructed world, theos that describes how Filipinos construct a sacred world, and ethos that describes how Filipinos construct a moral world. To extend the argument of the discourse, a rejoinder is provided in response to scholars' criticisms and approval of Mercado's anthropological perspective on the study of Filipino philosophy.
\end{abstract}

Keywords: Mercado, Filipino philosophy, cultural philosophy, ethnographic method

\section{Response to Scholars}

fter establishing the significance of Mercado's anthropological
perspective in the study of Filipino philosophy through the analysis
of the components of his book, Elements of Filipino Philosophy, we now

(C) 2014 Emmanuel D. Batoon

http://www.kritike.org/journal/issue 15/batoon december2014.pdf

ISSN 1908-7330

$(\mathrm{cc}) \mathrm{BY}$-NC 


\section{MERCADO'S ANTHROPOLOGICAL PERSPECTIVE}

proceed to the analysis of scholars' reaction to Mercado's anthropological perspective on the study of Filipino philosophy.

\section{A. Critics}

\section{Emerita Quito}

Emerita Quito, in footnote number eight (8) of her paper entitled, The Filipino and the Japanese Experience in Lectures on Comparative Philosophy makes the following comments regarding Mercado's study:

Leonardo Mercado, SVD pioneered in writing about Filipino Philosophy. Credit must be given to him for pioneering, but until now there is still opposition to his theories. Scholars find his work to be merely linguistic. ${ }^{1}$

In the main body of her text she says the following:

The question now is: Is there an indigenous Filipino Philosophy? Or, are there any Filipino philosophers? It is deplorable to answer the question in the negative. Despite the pioneering work of one Filipino author, it is premature to speak of a Filipino philosophy, moreover, of a Filipino philosopher. She cites a number of reasons: 1) ... the typical Filipino is full of mirth and optimism, he does not brood over the philosophical problems of life and death. Besides, he does not have the time ... ;2) ... there is a universal fear of philosophy... In the present set-up in the Philippines, it is doubtful whether we can produce a Filipino thinker who can, with freedom and dignity, speak unafraid of themes that may run counter to orthodoxy.... In the Philippines, when one dabbles in Philosophy, one is exposed to ridicule like the proverbial Pilosopong Tasio who is mentioned in a derogatory manner; and 3)....Even our language does not lend itself to philosophy; There are no equivalents to words like being, essence, existence, becoming, actuality, transcendence. ... Our mentality or our Weltanschauung

1 Emerita S. Quito, "The Filipino and the Japanese Experience," in Lectures on Comparative Philosophy (Manila: De la Salle University, 1979), 34.

(C) 2014 Emmanuel D. Batoon http://www.kritike.org/journal/issue 15/batoon december2014.pdf ISSN 1908-7330 
is too personal and emotional to allow a more transcendental way of viewing things. ${ }^{2}$

In response to Quito, one can say that Mercado's goal is not to be a Filipino philosopher in the likes of Sartre and Heidegger. He is not engaged in formulating an academic-universal philosophy using an abstract intellectual method and writing this down in an academic treatise. He merely interpreted the ordinary mainstream Filipinos' produced cultural philosophy that is shown in their everyday language and behavior. By adopting an anthropological perspective, he wished to show that Filipinos philosophize about their life as a culturally organized people.

Perhaps, Quito realized Mercado's anthropological point later when she used Levi-Strauss's Structuralist Anthropology in understanding the Filipino Volkgeist:

"Philosophy" or "love of wisdom" is a Greek concoction which must be understood in the spatiotemporal context of Pythagoras, who coined the term.... It must be mentioned that long before the ancient Greeks formulated the word "philosophy," the Indians had used darshana which means "point of view," and the Chinese sages had used the term tao to designate primitive wisdom. ... Why should we now in the Philippines be so pre-occupied about whether there is or there is no Filipino philosophy? Why the heated and unnecessary discussion of whether we are using the term in its original Greek connotation when we should be more receptive to the Asian concept? ... I have no qualms of using the term Volkgeist instead of philosophy to describe our spirit, our diwa, which characterizes the inhabitants of these seven thousand islands in the Pacific. Once we let go of our penchant for the Greek concept of philosophy, the true Filipino spirits or diwa will emerge and may well be the general seed of future philosophical and academic thinking. ${ }^{3}$

If Quito reiterates scholars' finding that Mercado's study as "purely linguistic", Alfredo Co finds Mercado's study futile.

2 Ibid., 28-29.

${ }^{3}$ Emerita Quito, "Structuralism and the Filipino Volkgeist," in A Life of Philosophy: Festschrift in honor of Emerita S. Quito (Manila: De la Salle University Press, 1990), 732.

(c) 2014 Emmanuel D. Batoon http://www.kritike.org/journal/issue 15/batoon december2014.pdf ISSN 1908-7330 


\section{MERCADO'S ANTHROPOLOGICAL PERSPECTIVE}

\section{Alfredo Co}

Alfredo Co makes the following comments to Mercado's enterprise:

I certainly respect the diligence undertaken by my colleagues in philosophy, but I definitely disagree with what they refer to as Filipino philosophy. After over twenty years of comparing Bisaya, Ilokano, Bicolano, Tagalog and even Ilonggo, Leonardo N. Mercado, SVD is still on the same level of comparing them but he has not established what can be categorically claimed as the Filipino philosophy. ${ }^{4}$

\section{Then Co suggests:}

Those of us who are still toiling in a desperate search for the Filipino soul and the Filipino philosophy are really lagging behind. Many of our Filipino thinkers have already done their part by philosophizing and writing. In the process, they have become philosophers. And because these are Filipinos philosophizing, then we call the body of their works Filipino philosophy. For when the Filipino philosophizes, he at once claims the right to claiming his own views. ${ }^{5}$

Co is correct in understanding that Mercado's book is exploratory in nature but perhaps Co is unjustified when he accused Mercado of failing to come up with a "categorical" conclusion regarding the "essential" Filipino philosophy. Mercado did not do this precisely because he cannot do it; he is not the creator of Filipino philosophy - the Filipino people are. Even the Filipino people cannot create a categorical "essential" Filipino philosophy because it is an artificial cultural symbolic system, not a natural phenomenon, that changes through time and space by way of cultural acculturation like assimilation or amalgamation.

Mercado's study, though limited, is an interpretation of the Filipino people's worldview that can never be lumped with the body or "sum" of Filipinos "doing philosophy" especially those who use explicit or implicit academic philosophical theories as norms in prescribing what "should" happen in Philippine society, instead of using empirical Philippine social

${ }^{4}$ Alfredo P. Co, "Doing Philosophy in the Philippines: Fifty Years Ago and Fifty Years from Now," in Karunungan, 21 (2004), 11.

${ }^{5}$ Ibid., 17.

(C) 2014 Emmanuel D. Batoon

http://www.kritike.org/journal/issue 15/batoon december2014.pdf

ISSN 1908-7330 
realities to verify the explanatory power of these academic philosophical theories.

If Co finds Mercado's study futile, Nicanor Abueg finds Mercado's study "scientistic".

\section{Nicanor S. Abueg}

Nicanor S. Abueg expected Mercado to follow the existential phenomenological method which required that he perform an epoche or bracketing of all his prejudices about Filipinos so that he could return the original Filipino experience to arrive at the eidos of Filipino philosophy. But Mercado did not meet his expectations because he used a scientific anthropological approach in studying Filipino philosophy. In Abueg's mind, Mercado "placed himself above the subjects of his inquiry," 6 and "assumed that the philosophy of a culture is implied in the people's way of thinking and behaving."7

Abueg was wrong in expecting that Mercado suspended all his prejudices in studying the Filipino so that he could arrive at the essence of the existential individual Filipino consciousness. Absolute epoche and eidetic reduction cannot be done as long as an individual knower is an embodied subjectivity because s/he is always situated in a cultural world. But Mercado's use of anthropological perspective provided the condition of possibility through which he can provide an emic or insider view, as opposed to etic or outsider view, of the lived Filipino social-cultural world that is constituted in and through the Filipino language and behavior.

If Abueg finds Mercado's study "scientistic" Feorillo Demeterio III finds Mercado's study lacking in critical reflection.

\section{Feorillo Demeterio III}

Feorillo Demeterio does not directly react to Mercado's book but implicitly criticizes it for it lacks a critique of power in understanding the Filipino worldview based upon an anthropological perspective. Demeterio opines:

The phase of early indigenization of Abulad, which is equivalent to the interpretation of the Filipino worldview of Nakpil-Zialcita, is also not as promising as critical philosophy. ... The main problem with this way

${ }^{6}$ Nicanor S. Abueg, “Leonardo N. Mercado's Elements of Filipino Philosophy by Leonardo N. Mercado, SVD," in Philippine Studies, 22 (1974), 384.

${ }^{7}$ Ibid.

(c) 2014 Emmanuel D. Batoon

http://www.kritike.org/journal/issue 15/batoon december2014.pdf

ISSN 1908-7330 
of doing Filipino philosophy has been revealed already by Nakpil-Zialcita when he questioned the philosophic nature of the concern of this way of philosophizing. Having doubted its philosophic nature, Nakpil-Zialcita placed its being philosophic on its purpose which is to theorize further on the impact of the Filipino world-view on the present and future of the Filipino. Instead of doing the post-sociological and post anthropological speculations, many of our philosophy professors and students had been mired behind the trail of the social scientists and other cultural experts whose tasks they poorly attempted to duplicate. ${ }^{8}$

Is Mercado interpretation of the Filipino worldview devoid of any critical and liberative character? If one were to ask the traditional Critical Theory question, "For whom and against whom is Mercado's book?," what could be the answer? If one situates Mercado's book in its historical context, then one finds that his work has something to do the clamor for 'Filipinization' which is a part of the liberation of Filipinos from colonial mentality. He says:

The clamor for Filipinization has reached the ears of various sectors of the nation. For instance the demand for Filipinizing education. ... Another filed is the indigenization of theology because Christianity in the Philippines has been preached in Western categories. But indigenizing theology, as encouraged by Vatican II, need Filipino philosophy for its basis. In other words, Filipino philosophy is a means of liberating the Filipino from mental bonds. ${ }^{9}$

In addition, Mercado's focus on the Filipino sakop as a society that follows the communalist barangay ${ }^{10}$ poses an alternative model of social life to the so-called leftist communist society of the communist party of the

${ }^{8}$ F.P.A. Demeterio III, "Thought and Socio-Politics: An Account of the Late Twentieth Century Filipino Philosophy," in F.P.A. Demeterio's Philosophy and Cultural Theory Page, 20, Accessed 30 June 2011, <https://sites.google.com/site/feorillodemeterio/filipinophilosophy essays>.

${ }^{9}$ Mercado, Elements of Filipino Philosophy, 7.

10 William Henry Scott, Barangay Sixteenth Century Philippine Culture and Society (Quezon City: Ateneo De Manila University Press, 1994).

(C) 2014 Emmanuel D. Batoon

http://www.kritike.org/journal/issue 15/batoon december2014.pdf

ISSN 1908-7330

(cc) $\mathrm{BY}-\mathrm{NC}$ 
Philippines or the rightist capitalist society of the oligarchs or the so-called centrist new society of Pres. Ferdinand Marcos.

\section{Andrew Gonzales}

Finally, after learning about the criticisms of professional philosophers on Mercado's anthropological perspective, it is vital to turn to the analysis of a social scientist-linguist's criticism on Mercado's book. The linguist, Bro. Andrew Gonzales, discusses the context of his criticism on Mercado's book as follows:

My own admittedly subjective view on this matter...is that this conscious research for a 'Filipino' social science is a red herring, that is, 'a diversion (unintentionally) intended to distract attention from the real issue' which in my opinion is the development of social science research in the Philippines for national development. This search for a social science that is 'Filipino' is to me narcissistic. In Greek mythology, Narcissus fell in love with his own image and in the process was turned into a flower! In general, it is my impression that certain felicitous results in human life arise as a result of the convergence of spontaneous currents. Where one tries to 'plan' too much, the results can be unhappy ones. In many areas of human life, one is 'performing' and this 'performing' can lead to a lack of performance. ${ }^{11}$

Gonzales eventually claims that this futile attempt to "Filipinize" the social sciences had its beginnings in theology and philosophy:

In the area of philosophy and theology, perhaps the best known and fully conscious attempt to arrive at 'elements' of Filipino Philosophy and Theology has been Leonardo Mercado's attempts. While the efforts have been valiant and consistent, I am afraid that the results have been infelicitous. What Mercado has done in his books $(1974,1975)$ is to cull from the findings of cultural anthropology and folklore 'elements' that could

${ }^{11}$ Andrew B. Gonzales, "Indigenization of the Social Sciences A Red Herring?" in Indigenous Psychology: A Book of Readings (Diliman, Quezon City: AKADEMYA NG SIKOLOHIYANG PILIPINO Philippine Psychology Research and Training House,1990), 110111.

(C) 2014 Emmanuel D. Batoon http://www.kritike.org/journal/issue 15/batoon december2014.pdf 
constitute seminal ideas for what traditional Western theology and philosophy have included in their considerations: God, Man, the Universe, Man's Relation with God and with Others. What results, it seems to me (Gonzales 1976), is a labeling process, a matter of giving Philippine names, to realities learned in a Western tongue. If this is what Filipino philosophy and theology are it is not too interesting. ... I am pointing out that this conscious search has not yet resulted in an interesting body of knowledge; perhaps the very logic and structure of the enterprise, when 'performed' this way, inevitably gives rise to glorified labeling, a less obvious form of translation. ${ }^{12}$

The attempt at "Filipinization" of the Social Sciences is not at all narcissistic. It is high time that Filipinos start talking about themselves to understand themselves (ganito tayo)' instead of explaining to westerners who they are (ganito kami). Mercado's book is one the genuine at attempts at Filipinization.

Mercado's work is not also a mere performance. He provides empirical linguistic and behavioral evidence to justify his claims and his use of the terminologies on the elements of other culture's philosophies is meant to serve as heuristic devices to elucidate his empirical findings on the elements of Filipino philosophy to fellow Filipinos trained in Western academic philosophies. As Mercado puts it:

This study is not comparative. Whatever is mentioned about Greek philosophy (particularly Plato and Aristotle) and about Oriental philosophy is just for the sake of bringing things clearly to light. That is the purpose of the light-and-shadow literary device. ... Secondly, this work is intended for non-ordinary readers of higher college level, that is, readers who have received a Western education and unwittingly have been trained to think in the Western bias. ${ }^{13}$

If the aforementioned scholars criticized Mercado's anthropological perspective on the study of Filipino philosophy, other scholars made it a model framework from which they patterned their own studies.

${ }^{12}$ Ibid., 112.

${ }^{13}$ Mercado, Elements of Filipino Philosophy, 13.

(C) 2014 Emmanuel D. Batoon

http://www.kritike.org/journal/issue 15/batoon december2014.pdf

ISSN 1908-7330

(cc) $\mathrm{BY}-\mathrm{NC}$ 


\section{B. Admirers}

\section{Dionisio Miranda}

Fr. Dionisio Miranda gathers Mercado's insight on loob and says:

Leonardo Mercado, who believes that loob is a holistic concept untranslatable by a single word and hence associated with a variety of meaning: (a) malay, (b) intellect, senses, mind, judgment, decision, (c) desire, or will, (d) human heartedness, moral goodness, conscientious, (e) conscience, (f) love. In this last he notes that loob and body are the same as a man alive. Loob is not distinct from man's faculties as long as he is alive; not so in death. ${ }^{14}$

Then, Miranda used Mercado's concept of loob as model in formulating a psychological-moral account of the concept of loob. Then he followed Mercado's anthropological (cultural) approach. Miranda discusses his cultural approach:

My own particular concerns lead toward an understanding of loob in its implication for philosophical anthropology in general and for moral anthropology in particular. But, within the strands of Filipino thought I would consider myself broadly in the mainstream of those who are concerned with philosophy of culture or the inculturation, indigenization and contextualization of theology. More specifically I would count myself around those who have accepted the Filipinization of philosophy and theology as a valid and worthwhile project . ${ }^{15}$

Then he discusses his method in this way:

Forced to give my method some kind of label, I initially thought of "cultural exegesis," later I weighed the merits of "thematization of culture." ... the notion in fact borrows from the linguist's distinction between emic

${ }^{14}$ Dionisio M. Miranda, SVD, Loob The Filipino Within: A Preliminary Investigation into a Pre-Theological Moral Anthropology (Manila: Logos Publications, Inc., 1988), 2.

${ }^{15}$ Ibid., 3. 
(from the inside) and etic (from the outside) analysis of cultural system. Native exegesis of culture would then be the equivalent of linguistic, emic analysis, i.e., the description and analysis of a culture by one of its members. ${ }^{16}$

Miranda's substantive findings on loob as a complex psycho-moral reality is that it is composed of the concepts of sarili (man as self), psychological personality and moral character as two dimensions of sarili, categories of loob, distinctive constituents of katauhan, and distinctive constituents of pagkatao. ${ }^{17}$ Given this psycho-moral implication of the concept of lobo, Miranda also extends Mercado's concept of loob to include the idea of labas which Miranda interpreted as referring to the in-between or pagitan, ${ }^{18}$ which eventually leads to the idea of intersubjective relationships or pakikipagkapwa-loob. Hence, Miranda converted the concepts of loob, kapwa, and labas as ethical categories to serve as conditions of possibility for the formulation of a formal Filipino theory on ethical action and special ethics. ${ }^{19}$

If Miranda translated Mercados' interpretation of the concept of loob into a pscho-moral concept, Alejo elaborated Mercado's interpretation of the concept of loob by interpreting it as a TEXT.

\section{Albert Alejo}

Fr. Albert Alejo acclaimed Mercado's book as the "first systematic study on Filipino philosophy that launched the most fruitful twenty years of research on the topic by his students" 20 though it is not the first to deal with the study of Filipino philosophy (Zialcita) ${ }^{21}$ and elaborated Mercado's findings by doing a Ricoeurian phenomenological hermeneutic ${ }^{22}$ reading of the concept of loob.

He first subjected the concept of loob to a hermeneutics of suspicion ${ }^{23}$ where he investigated the misconceptions about loob (tianak ng kalooban) ${ }^{24}$ as

\footnotetext{
${ }^{16}$ Ibid., 3-4.

17 Ibid., 23-44.

18 Ibid., 77-100.

${ }^{19} \mathrm{Ibid} ., 101-124$.

${ }^{20}$ Albert Alejo, Tao Po! Tuloy! (Quezon City: Office of Research Publications, Ateneo de Manila University,1990), 13.

${ }^{21}$ Fernando N. Zialcita, “Forms of A Filipino Philosophy," in Solidarity, 7 (1972), 4-1.

${ }^{22}$ Paul Ricoeur, Hermeneutics and the Human Sciences, trans. by John B. Thompson (Cambridge: Cambridge University Press, 1981).

${ }^{23}$ Paul Ricoeur, Freud and Philosophy: An Essay on Interpretation, trans. by Dennis Savage (New Haven: Yale University Press, 1998), 27.

${ }^{24}$ Alejo, Tao Po! Tuloy!, 5-7.

(C) 2014 Emmanuel D. Batoon

http://www.kritike.org/journal/issue 15/batoon december2014.pdf

ISSN 1908-7330 
a word or a sign. Then, he made a hermeneutics of retrieval ${ }^{25}$ of the eidos of loob which he educed from his lived experience of participation. ${ }^{26}$ Alejo finds that the loob is not just a concept but a "text." As a "text," it is not found in the language that is loob by itself and in itself, but in the encounter between the language of loob and the user of the language of loob. He showed this through a review of how Filipino scholars interpreted the ostensive reference of the word loob, including that of Mercado's interpretation of loob as holistic and interior. But instead of digging for the hidden similar unconscious logical structure that lies behind the different ostensive reference of the language of loob through an analysis of grammar and syntax, as a traditional structuralist scholar would do, he looked for the "non-ostensive" reference that the word loob "revealed. In this way, he interpreted loob as a "metaphor." 27 Alejo finds that, "When one recognizes this metaphor, he or she looks at its literal meaning in the context of everyday experience and listen to what it says from and within its literal meaning;" 28 then one realizes that it is really a symbol that "reveals" a phenomenon which is a "wide world." 29

He continues by saying that this "wide world" is a "reached-knownworld" (daigdig ng abot-malay)30, a "reached-felt-world" (daigdig ng abotdama) $)^{31}$ and a "reached- acted-world" (daigdig ng abot-kaya) ${ }^{32}$. The "reachedknown-world" is composed of the known self, other, world and God. The "reached-felt-world" is comprised of the felt-self (interiority), felt others (commiseration), felt-world (involvement) and felt-God (fear and attraction). And the "reached-acted-world" is composed of the known and felt-self as a construction, the known and felt-self with other as an embodied self, the known and felt-self with the world as possessing temporality or possibilities and the known and felt-self with God as a struggle and hope.

In the end, Alejo qualifies that the wide world of loob is a reachedworld (daigdig na abot) 33 to add the idea that Filipino society as a world is based on what Filipinos can envision as the horizon of reality (abot tanaw ng meron) ${ }^{34}$ and at the same time, a world that can only envision so much of reality (abot-dili) ${ }^{35}$ because, of Filipinos' limited consciousness, lukewarm

\footnotetext{
${ }^{25}$ Ricoeur, Freud and Philosophy, 28.

${ }^{26}$ Ibid., 7-9.

${ }^{27}$ Ibid., 63.

${ }^{28}$ Ibid., 65.

${ }^{29}$ Ibid., 80.

30 Ibid., 85.

${ }^{31}$ Ibid., 91.

${ }^{32}$ Ibid., 100.

${ }^{33} \mathrm{Ibid}$.

${ }^{34}$ Ibid., 112.

${ }^{35} \mathrm{Ibid} ., 113$.
} 
feelings, and disbelief in their capacity. This limited view of the world could only be extended if Filipinos would resolve to 'participate' to extend it.

If Alejo extended Mercado's interpretation of the Filipino concept of loob into the understanding that loob is a TEXT, Dr. Timbreza elaborated Mercado's study of Filipino philosophy by gathering Filipino oral literary data to complement Mercado's use of linguistic data in studying Filipino philosophy.

\section{Florentino Timbreza}

Florentino Timbreza publicly admitted that Mercado inspired him to conduct his own investigations on the Filipino philosophy which he entitled, Pilosopiyang Pilipino. ${ }^{36}$ Timbreza extended Mercado's interpretation of Filipino philosophy based on the analysis of Filipino languages by using Filipino oral literature in the form of "sayings" (kasabihan) from a number of ethnic linguistic groups which included not only the three major groups (Tagalog, Visaya, Bicol) that Mercado studied but also from relatively smaller ones like the Igorot, Kalinga-Banao, Tiruray, Tausug, Maranaw and Maguindanaw. ${ }^{37}$

If the philosophers' admired Mercado's study, so too did scientists.

\section{Virgilio Enriquez}

Dr. Virgilio Enriquez, a leading advocate of indigenous social psychology (Sikolohiyang Pilipino) in the Philippines, commends Mercado's interpretation of the Filipino concept of loob and its relation to the Filipino moral values wants it to be further studied by looking at it from the perspective of empirical psychology to arrive at an understanding of the empirical Filipino social psyche or collective consciousness (kamalayan) and morality. ${ }^{38}$

Hence, Enriquez together with Amelia B. Alfonso conducted an empirical social psychological linguistics study on the Tagalog social values. Their findings show the following Tagalog people's social values: 1) Importance of human relationship; 2) High regard to emotion and to the

${ }^{36}$ Florentino T. Timbreza, Pilosopiyang Pilipino (Manila: Rex Book Store, 1982).

${ }^{37}$ Ibid., ix.

${ }^{38}$ Virgilio G. Enriquez and Amelia B. Alfonso, "The Worldview and Weltanschauung of the Filipinos as Reflected in the Tagalog Language," in The Filipino Weltanschauung in Languages, Literature, Popular Culture, Visual Arts and Other Fields (Philippines and Singapore: Philippine Psychology Research House, Philippines and Institute for Southeast Asian Studies, Singapore, 1980), 15.

(C) 2014 Emmanuel D. Batoon

http://www.kritike.org/journal/issue 15/batoon december2014.pdf

ISSN 1908-7330

(cc) BY-NC 
welfare of other people; 3) Concept of success is one which is also for everybody and not only for the individual. ${ }^{39}$

If Enriquez examined the implications of Mercado's interpretation of the Filipino concept of loob to the study of empirical Filipino socialpsychology, Jocano complemented Mercado's anthropological linguisticphenomenological approach with Clifford Geerz' anthropological "thick description" approach in the study of Filipino philosophy.

\section{Felipe Landa Jocano}

Dr. Felipe Landa Jocano, an anthropologist and one of the panel of examiners in Mercado's dissertation defense in 1973,40 complements Mercado's anthropological linguistic-phenomenological interpretation of mainstream Filipinos' worldview using Clifford Geertz' anthropological thick description methodology in understanding selected Filipino "rural villagers" who were the recognized thinkers whose local knowledge of the native lore is admired and respected. ${ }^{41}$ His data was gathered from his unpublished field notes and previously published articles and books ${ }^{42}$.

Jocano's findings show that Filipinos view their world is composed of layered but continuous structures that perform specific functions in defining the self of man (natural, biological, communal, social, normative, ethical, moral, aesthetic, teleological, and ideological).

The natural dimension, ${ }^{43}$ with its likas (energy) and bisa (life force), makes a man grow as an animal. The biological dimension ${ }^{44}$ is the impact of nature to a man's well-being (health) or non-well-being (illness). The communal dimension ${ }^{45}$ reveals a man's kin or blood relations. The social dimension ${ }^{46}$ is the impact of a man's communal relations that affects his or her well-being or non-well-being. The normative dimension ${ }^{47}$ sets the standards of behavior that a man must follow in communal life. The ethical dimension ${ }^{48}$ is a man's conformity or non-conformity with the norms of behavior set by his or her community. The moral dimension ${ }^{49}$ is the "honor"

\footnotetext{
${ }^{39}$ Ibid., 20-21.

${ }^{40}$ Leonardo N. Mercado, Elements of Filipino Philosophy, Ph.D. Dissertation (Manila: UST Graduate School, 1973), ii.

${ }^{41}$ Ibid., 12-13.

${ }^{42}$ Ibid.

${ }^{43}$ Ibid., 15-36.

${ }^{44}$ Ibid., 37-50.

${ }^{45}$ Ibid., 51-64.

${ }^{46}$ Ibid., 65-84.

47 Ibid., 85-96.

48 Ibid., 111-122.

${ }^{49}$ Ibid., 123-134.
} 


\section{MERCADO'S ANTHROPOLOGICAL PERSPECTIVE}

that a man should show in communal life. The aesthetic dimension ${ }^{50}$ is the pleasure that he or she gets out of a morally ordered life. The teleological dimension $^{51}$ is a man's belief regarding the end towards which he or she should tend. The ideological dimension ${ }^{52}$ is the interior order of meanings that provide the frame of life and purpose for a man. This represents the core of loob from which an individual is able to understand and respond to the dimensions that condition his or her life.

\section{Final Words}

The paper started tracing Fr. Leonardo N. Mercado's anthropological perspective on the study of Filipino philosophy through an explanatory content analysis of his book's substantive theoretical framework, method, and findings on Filipino philosophy and through a critical content analysis of scholars' analysis of Mercado's perspective.

The analysis of the components of Mercado's book shows the social significance of his anthropological perspective on the study of Filipino philosophy in terms of the following: 1) The anthropological perspective, as a substantive theoretical framework, is appropriate because it brings to light the Filipino worldview; 2) The anthropological ethnographic method is adequate because it is able to gather and analyze data on Filipinos as a culturally organized group; 3) The anthropological perspective provides substantive findings about the Filipino worldview in terms of logos, ontos, and ethos. The logos highlights the Filipino's social psychological way of thinking; the ontos shows the intuitive concern for the being of interpersonal relationships. They conceive the individual man as loob who needs to be fixed and constituted through interpersonal relations in society as sakop. They have to physically sustain and concretize the sakop. They have to naturalize the sakop by humanizing nature. They have to rationalize the sakop by sacralizing it, by formulating an ethos that regulates the behavior of the members toward the sakop, and by constructing rituals to make the members affirm, memorialize, and celebrate the sakop.

The tracing of Mercado's study continued by the analysis of scholars' reaction to his study. One group of scholars criticized his study on grounds that his work is a mere translation or performance, or that his work is futile because he has not produced a categorical account on the "essential" Filipino philosophy, or that his work smacks of scientism. The critics merely imposed their biases unto Mercado's work without fully understanding what an anthropological perspective on Filipino philosophy really means. But, some

\footnotetext{
50 Ibid., 135-144.

51 Ibid., 145-160.

52 Ibid., 161-186.
}

(C) 2014 Emmanuel D. Batoon http://www.kritike.org/journal/issue 15/batoon december2014.pdf ISSN 1908-7330 
other scholars understood Mercado's perspective. Some of them philosophically elaborated Mercado's study by adding literary data form Filipino ethnic groups in the understanding of Filipino philosophy or by interpreting the loob as TEXT and a metaphor. Some of them elaborated Mercado's study by using it as model in formulating the Filipino psychomoral character or the Filipino psycho-social character. And some of them complemented Mercado's anthropological linguistic-phenomenological perspective on mainstream Filipino philosophy with an anthropological "thick description" on rural village Filipinos' philosophy.

After tracing Mercado's anthropological perspective on the study of Filipino philosophy, what else could young Filipino philosophy scholars do on the study of Filipino philosophy?

Given the premise that cultural philosophies are man-made symbolic systems whose meanings can change in time and space through cultural assimilation and amalgamation, it is therefore, necessary that contemporary Filipinos' (who are not just members of the Filipino nation but also citizens of the virtual world and have worked all over the world) language and behavior be studied to check whether or not they manifest the same Filipino worldview discovered by Mercado in the 1970s. It may also be vital to interview them, individually and as a focused group, to ascertain if they still conform to the Filipino worldview that they have been made to interiorize earlier in their lives.

To pursue this kind of research, however, requires an interplay of forces: culture, structure, and agency.

Research culture provides the worldview on research that frames the research structure and research agency of the members of academe. The research culture which the research on Filipino philosophy demand is a worldview that has the following: 1) a clear logos or thinking on the significance and value of the research on Filipino philosophy as an academic, philosophical pursuit; 2) a clear account of the ontos or reality of the Filipino worldview as output of this kind of research; and 3) a clear ethos or ethics on how to conduct this type of research.

Research structure refers to the "system of opportunities" available to researchers. The structural supports that this kind of research requires includes social science theoretical and methodological courses in the curriculum of professional philosophical education, fielding of teachers and research supervisors versed in both theories and research methods in philosophy and in the social sciences, organization of conferences and workshops that serve as venues for the public presentation of research results, and allotment of space in existing journals, if not altogether the creation of new journals for the publication of this type of research. This

(c) 2014 Emmanuel D. Batoon

http://www.kritike.org/journal/issue 15/batoon december2014.pdf

ISSN 1908-7330 
academic structural support also entails financial subsidies and the continuous exercise of political will.

The needed exercise of agency to fulfill this kind of research comes from two sources: school administrators and research proponents.

School administrators have to exercise their agency by making tough decisions as regards the building of the much-needed structural support. But such will not be a daunting task if they really want to understand how ordinary Filipinos imagine the nation and exercise their reflexivity to see what is best to adapt from the Western academic philosophical theories for the development of the nation.

Research proponents, on the other hand, have to exercise their agency by being more knowledgeable in philosophy as well as in the social sciences in terms of theory, method, and research practice. They have to dive into the sources of empirical data on Filipino philosophy as well as literature on the Philippines and the Filipinos. They also need to seek help and encouragement from other scholars because the task is sometimes too daunting and frustrating. They have to look for a reason or a passion to motivate themselves to carry on with the task despite cultural and structural barriers. Finally, they have to work hard to make their research results known to politicians who promised to make policies and programs that serve the interest of the Filipino nation.

If all these things are possible, then other scholars can join Fr. Leonardo N. Mercado in celebrating the best in the Filipino!

Department of Philosophy, University of Santo Tomas, Philippines

\section{References}

Abueg, Nicanor S., "Leonardo N. Mercado's Elements of Filipino Philosophy by Leonardo N. Mercado, SVD," in Philippine Studies, 22 (1974), 384386.

Abulad, Romualdo E., "Options for a Filipino Philosophy," in Karunungan, 1 (1984), 17-30.

"Contemporary Filipino Philosophy," in Karunungan, 1:5 (1988), $1-13$.

Abulad, Romualdo E., Florentino T. Timbreza and Herminia V. Reyes, "Pilosopiyang Pilipino," in Ensayklopedia ng Pilosopiya, ed. by Emerita S. Quito (Manila: De La Salle University of Press, 1993).

Alejo, Albert, Tao Po! Tuloy! (Quezon City: Office of Research Publications, Ateneo de Manila University, 1990).

Batoon, Emmanuel D., A Guide to Thesis Writing in Philosophy Part One: Proposal Writing (Manila: REJN Publishing, 2005).

(C) 2014 Emmanuel D. Batoon

http://www.kritike.org/journal/issue 15/batoon december2014.pdf

ISSN 1908-7330

(cc) BY-NC 
Co, Alfredo P., "Doing Philosophy in the Philippines: Fifty Years Ago and Fifty Years from Now," in Karunungan, 21 (2004), 1-18.

Cresswell, John W., Research Design: Qualitative, Quantitative, and Mixed Methods Approaches $2^{\text {nd }}$ ed. (Thousand Oaks, California: Sage Publications, Inc., 2002).

Demeterio III, F.P.A., "Thought and Socio-Politics: An Account of the Late Twentieth Century Filipino Philosophy," in F.P.A. Demeterio's Philosophy and Cultural Theory Page, April 2002, Accessed 30 June 2011,<https://sites.google.com/site/feorillodemeterio/filipinophiloso phyessays $>$.

, “Re-reading Emerita Quito's Thoughts Concerning the Underdevelopment of Filipino Philosophy," in F.P.A. Demeterio's Philosophy and Cultural Page. April 2002, Accessed 30 June 2011,<https://sites.google.com/site/feorillodemeterio/filipinophiloso phyessays $>$.

Enriquez, Virgilio. G., Indigenous Psychology: A Book of Readings (Quezon City: Akademya ng Sikolohiyang Pilipino, 1990).

Enriquez, Virgilio G. and Amelia B. Alfonso, "The Worldview and Weltanschauung of the Filipinos as Reflected in the Tagalog Language," in The Filipino Weltanschauung in Languages, Literature, Popular Culture, Visual Arts and Other Fields (Philippines and Singapore: Philippine Psychology Research House, Philippines and Institute for Southeast Asian Studies, Singapore, 1980).

Gonzales, Andrew B., "Indigenization of the Social Sciences A Red Herring?," in Indigenous Psychology: A Book of Readings (Diliman, Quezon City: AKADEMYA NG SIKOLOHIYANG PILIPINO Philippine Psychology Research and Training House, 1990).

Gripaldo, Rolando M., Filipino Philosophy Traditional Approach Part 1, Section 3rd ed. (Washington, D.C.: C \& E Publishin Inc. and the Council for Research in Values and Philosophy, 2009).

Jocano. Felipe L., Filipino Worldview (Quezon City: PUNLAD, 2001).

Mercado, Leonardo N., Elements of Filipino Philosophy, Ph.D. Dissertation in Philosophy (Manila: UST Graduate School, 1973). Elements of Filipino Philosophy (Tacloban City: Divine Word University Publication, 1974).

Miranda, Dionision, Loob: The Filipino Within (Manila: Divine Word Publications, 1989).

Neuman, W. Lawrence, Social Research Methods Qualitative and Qualitative Approach, $6^{\text {th }}$ ed. (Boston: Pearson Education, Inc., 2006).

Payne, Geoff and Malcolm Williams, "Generalization in Qualitative Research," in Sociology, 32 (2005), 295-314.

(c) 2014 Emmanuel D. Batoon http://www.kritike.org/journal/issue 15/batoon december2014.pdf ISSN 1908-7330 


\section{MERCADO'S ANTHROPOLOGICAL PERSPECTIVE}

Quito, Emerita S., The State of Philosophy in the Philippines (De La Salle University Monograph Series No.5. Manila: De La Salle University Research Center, 1983).

"The Filipino and the Japanese Experience," in Lectures on Comparative Philosophy (Manila: De la Salle University, 1979).

"Structuralism and the Filipino Volkgeist," in A Life of Philosophy: Festschrift in honor of Emerita S. Quito (Manila: De la Salle University Press, 1990), 724-741.

Radin, Paul, Primitive man as philosopher (New York: Dover Publications, Inc., 1957).

Redfield, Robert, The Primitive World and Its Transformation (Ithaca, New York: Cornell University Press, 1953).

Reyes, Ramon C., "Sources of Filipino Thought," in Philippine Studies, 21 (1973), 429-37.

Tassi, Aldo, "Modernity as Transformation of Truth into Meaning," in International Philosophical Quarterly, 22 (1982), 185-194.

Timbreza, Florentino T., Pilosopiyang Pilipino (Manila: Rex Book Store, 1982). 9-35.

"Understanding Filipino Philosophy," in Karunungan, 3 (1986),

Zialcita, Fernando N., "Forms of A Filipino Philosophy," in Solidarity, 7 (1972), 4-14.

(c) 2014 Emmanuel D. Batoon

http://www.kritike.org/journal/issue 15/batoon december2014.pdf

ISSN 1908-7330 